\title{
Health Belief Associated with Adherence to Health Protocol in Preventing Coronavirus Diseases on Patients' Family
}

\author{
Riza Fikriana $^{1 *}$ (D), Frastiqa Fahrany ${ }^{1}$ (D) Syahril Ali Rusli ${ }^{2}$ (D) \\ ${ }^{1}$ Department of Nursing, Sekolah Tinggi Ilmu Kesehatan Kepanjen, Malang, Indonesia; ${ }^{2}$ Mitra Delima Hospital, Malang, Indonesia
}

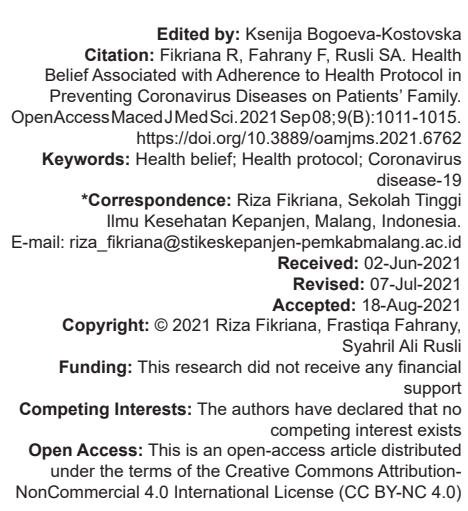

\section{Introduction}

Coronavirus diseases (COVID-19) are still a global problem. The World Health Organization (WHO) data show that the prevalence of COVID-19 cases is still increasing. As of March 2021, the number of confirmed positive COVID-19 has reached more than 118 million cases with the number of deaths more than 2.6 million. The prevalence of COVID-19 in Indonesia is also still increasing. The WHO data as of March 10,2021 , show that the number of positive confirmed cases has reached more than 1.3 million people with more than 37 thousand deaths [1]. The impact of the COVID-19 pandemic is very widespread, not only causing problems in respiratory disorders even resulting in death, but also increasing psychological burden problems in the community [2], [3], [4].

The WHO has issued health protocols for the public as a preventive effort to avoid the transmission of COVID-19 such as the use of masks, hand hygiene, and physical distancing [5]. However, the results showed that public awareness in complying with health protocols such as the use of masks is still very low [6]. This lack of adherence can have an impact on increasing the spread of COVID-19 in the community. Hospitals are environments that have a risk of spreading COVID-19. This spread can occur from health workers due to direct contact with patients and neglect of health protocols [7]. Not only health workers, all components in the hospital, such as the patient's family, are also at high risk of COVID-19 transmission [8]. So that efforts to prevent the transmission of COVID-19 in the hospital environment become a priority that should receive attention [9], [10].

The Health Belief Model (HBM) is a framework that explains the reasons that predict a person to perform health behaviors. $\mathrm{Hbm}$ construct includes perceived susceptibility, perceived severity, perceived benefit, perceived barrier, and self-efficacy [11]. HBM underlies a person to do self-care [12]. HBM is also able to predict one's intention in making behavior changes [13]. In addition, improved health belief will be able to increase one's awareness [14].

Studies on prevention efforts to prevent the transmission of COVID-19 in the community have been conducted. However, there are still not many studies that analyze adherence with health protocols for the families of patients in the hospital environment using 
the HBM approach. This study aims to analyze the relationship between health belief and the adherence of the patient's family in undergoing health protocols as an effort to prevent the transmission of COVID-19.

\section{Methods}

The design of the study is correlated with the cross-sectional study approach. The research population is the entire family of patients who are in Mitra Delima Hospital Malang, Indonesia, numbering 400 people. Samples were taken as many as 100 people with simple random sampling techniques. The variables studied refer to the HBM consisting of perceived susceptibility, perceived severity, perceived benefit, perceived barrier, and self-efficacy. In addition, another variable measured is adherence with health protocols. The research instrument uses a HBM questionnaire, consisting of questionnaires on perceived susceptibility, perceived severity, perceived benefit, perceived barrier, and self-efficacy that have been modified by researchers [15]. Statements on the health belief of each dimension consist of eight items of statements with a choice of answers - strongly agree, agree, doubt, disagree, and strongly disagree. While, the adherence questionnaire consists of three questions that include adherence in the use of masks, maintaining physical distance, and diligently washing hands. The scoring results for the variable HBM are further categorized into high confidence and low confidence. Confidence is high if the score is $\geq$ the median, the confidence is low if the score $<$ the median. Data analysis was conducted through Fisher test with 95\% significance using SPSS for Windows 25 program. The research protocol conducted an ethics test and has been approved by the Health Research Ethics Committee of the College of Health Sciences Kepanjen Malang, Indonesia with the number 176/S.Ket/KEPK/STIKesKPJ/II/2021.

\section{Results}

The results are presented in Table 1 (characteristics of respondents), Table 2 (distribution of frequency of health belief and adherence), and Table 3 (Fisher test results).

Table 1 shows that more than half of respondents were female $(58 \%)$, basically educated $(58 \%)$, and half of respondents received information about COVID-19 from the mass media (49\%).

Table 2 illustrates that in all dimensions of health belief most families of patients have a low level of health belief and are entirely non-compliant in carrying out health protocols.

Table 1: Respondent characteristic

\begin{tabular}{lll}
\hline Characteristic & Frequency (n) & Percentage \\
\hline Sex & & \\
$\quad$ Male & 42 & 42 \\
$\quad$ Female & 58 & 58 \\
Education & 4 & 4 \\
$\quad$ High & 38 & 38 \\
$\quad$ Moderate & 58 & 58 \\
$\quad$ Basic & & \\
Information Source & 49 & 49 \\
$\quad$ Mass Media & 17 & 17 \\
Village officer & 13 & 13 \\
Internet & 21 & 21 \\
Family & 100 & 100 \\
$\quad$ Total & & \\
\hline
\end{tabular}

Table 3 shows that the entire dimension of health beliefs is significantly correlated with compliance with the running health protocol. P-value results found that self-efficacy has the greatest significance to compliance with health protocols.

Table 2: Health beliefs and adherence to health protocol ( $n=100)$

\begin{tabular}{llll}
\hline Variable & Category & Frequency (n) & Percentage \\
\hline Health beliefs & High & 17 & \\
Perceived susceptibility & Low & 83 & 17 \\
Perceived severity & High & 15 & 83 \\
& Low & 85 & 15 \\
Perceived benefits & High & 15 & 85 \\
& Low & 85 & 15 \\
Perceived barriers & High & 14 & 85 \\
& Low & 86 & 14 \\
Self-efficacy & High & 13 & 86 \\
Adherence & Low & 87 & 13 \\
Adherence to health protocol & Yes & 9 & 87 \\
& No & 91 & 9 \\
\hline
\end{tabular}

\section{Discussion}

Coronavirus diseases (COVID-19) are highly contagious. Compliance with health protocols is one of the main keys to avoid transmission of this virus. The results of this study found that compliance with health protocols such as the use of masks, maintaining distance, and discipline of hand washing is still very low. This low compliance is associated with low health beliefs owned by the patient's family, such as selfefficacy, perceived benefit, perceived susceptibility, perceived barrier, and perceived severity.

Table 3: Result of Fisher test

\begin{tabular}{|c|c|c|c|c|c|}
\hline \multirow[t]{3}{*}{ Variable } & \multicolumn{4}{|c|}{ Adherence } & \multirow[t]{3}{*}{$p$-value } \\
\hline & \multicolumn{2}{|c|}{ Yes } & \multicolumn{2}{|l|}{ No } & \\
\hline & $\mathrm{n}$ & $\%$ & $\mathrm{n}$ & $\%$ & \\
\hline \multicolumn{6}{|c|}{ Perceived susceptibility } \\
\hline High & 5 & 29.4 & 12 & 70.6 & \multirow[t]{2}{*}{0.007} \\
\hline Low & 4 & 4.8 & 79 & 95.2 & \\
\hline \multicolumn{6}{|c|}{ Perceived severity } \\
\hline High & 4 & 26.7 & 11 & 73.3 & \multirow[t]{2}{*}{0.027} \\
\hline Low & 5 & $5, .9$ & 80 & 94.1 & \\
\hline \multicolumn{6}{|c|}{ Perceived benefits } \\
\hline High & 5 & 33.3 & 10 & 66.7 & \multirow[t]{2}{*}{0.003} \\
\hline Low & 4 & 4.7 & 81 & 95.3 & \\
\hline \multicolumn{6}{|c|}{ Perceived barriers } \\
\hline High & 4 & 28.6 & 10 & 71.4 & \multirow[t]{2}{*}{0.021} \\
\hline Low & 5 & $5, .8$ & 81 & 94.2 & \\
\hline \multicolumn{6}{|c|}{ Self-efficacy } \\
\hline High & 5 & 38.5 & 8 & 61.5 & \multirow[t]{2}{*}{0.002} \\
\hline Low & 4 & 4.6 & 83 & 95.4 & \\
\hline
\end{tabular}


Self-efficacy is the confidence of the patient's family to be able to behave in a disciplined manner in using masks, keeping distance, and avoiding crowds and washing hands. Low self-efficacy is significantly associated with low compliance. Self-efficacy is influenced by emotional responses. Self-efficacy has a very large role in determining the coping strategy used by a person in dealing with the problems faced. High self-efficacy will cause a person to have an adaptive coping strategy. Coping strategy affects health behavior [16]. Other studies show that self-efficacy is the main predictor of disease prevention behaviors [17]. High self-efficacy is associated with good adherence to health behaviors [18]. High self-efficacy accompanied by good social support will have a positive impact on one's behavior [19]. Efforts to improve self-efficacy can be done by providing education with a health belief approach [20].

Perceived benefits in this study are significantly related to compliance undergoing health protocols. The results found that most of the benefits showed it was still very low. This illustrates that the patient's family does not feel any meaningful benefit to him when they comply in undergoing health protocols. The benefits felt so that patients avoid the transmission of COVID-19 look still very low. So this becomes one of the factors related to the low compliance of the patient's family. Perceived benefits can affect a person's knowledge so this will be beneficial in improving health behaviors [21]. Another study found that perceived benefits will cause a person to make a visit to the health service to address the health problems they experience [22].

Perceived susceptibility describes the vulnerability felt by the patient's family to the possible risk of contracting COVID-19. The results showed that the families of patients were mostly considered to have a low risk of contracting Covid-19. This is one of the factors associated with low compliance in undergoing health protocols. Another study found that perceived susceptibility is influenced by narcissistic traits [23], [24]. Perceived susceptibility is significantly related to disease prevention behavior [25], [26]. The study was also supported by other studies that resulted in perceived susceptibility moderating disease screening behavior [27]. Family history is one of the factors associated with a person's susceptibility to disease [28], [29].

Perceived barriers in this study were also obtained significantly related to compliance with the running of health protocols. Perceived barriers are still very low in the patient's family. This indicates that the patient's family has high barriers to adherence to health protocols such as feeling discomfort when using a mask. This discomfort causes the patient's family to have low compliance. There are many factors that affect the perceived benefit in a person [30]. Lack of knowledge and low awareness are factors that affect the perceived barrier. So to lower the perceived barrier, it is necessary to provide interventions in the form of health education in order to increase knowledge and awareness [31]. Culture and social environment can also be a perceived barrier for a person [32]. Intervention development programs are needed to lower the perceived barrier [33].

Perceived severity of the patient's family is significantly related to compliance with the health protocol. The patient's family feels that COVID-19 is a serious disease so this can result in their low compliance of. Individuals with low perceived severity will result in low behavior changes. Meanwhile, individuals with high severity perceived result in a high change in behavior. This suggests that psychological responses affect a person's response to behavioral changes [34]. Other studies have also shown that perceived severity affects emotional response [35]. Perceived severity moderates the relationship between consciousness and intention [36]. Age and gender are also affected by perceived severity [37].

Health belief is a very important component in influencing the patient's quality of life, improving health behavior, and disease management. A person who has perceived susceptibility, perceived severity, and high perceived benefits shows a high level of adherence to health behaviors [38].

\section{Conclusion}

Perceived susceptibility, perceived severity, perceived benefit, perceived barrier, and self-efficacy have a significant effect on compliance with health protocols in efforts to prevent the transmission of COVID-19. The practical implication of this study is that health workers can promote health with a health belief approach to be able to improve the compliance of the patient's family in carrying out health protocols, namely, by the discipline of wearing a mask, maintaining a distance of at least $1 \mathrm{~m}$ and diligently washing hands.

\section{References}

1. World Health Organization. Coronavirus disease 2019 (COVID-19). Situat. Report. 2021;32:1-16.

2. Rahmani AM, Mirmahaleh SY. Coronavirus disease (COVID-19) prevention and treatment methods and effective parameters: A systematic literature review. Sustain Cit Soc. 2021;64:102568. https://doi.org/10.1016/j.scs.2020.102568 PMid:33110743

3. Megatsari $H$, Laksono AD, Ibad M, Herwanto $Y T$, Sarweni KP, Geno RA, et al. The community psychosocial burden during the COVID-19 pandemic in Indonesia. Heliyon. 2020;6(10):e05136. https://doi.org/10.1016/j.heliyon.2020.e05136

4. Nursalam N, Sukartini T, Priyantini D, Mafula D, Efendi F. Risk factors for psychological impact and social stigma among 
people facing covid-19: A systematic review. Syst Rev Pharm. 2020;11(6):1022-8

5. World Health Organization. Mask Use in the Context of COVID19. COVID-19 Infection Prevention and Control/WASH. Geneva: World Health Organization; 2020. p. 1-10.

6. Pratiwi AD. Gambaran penggunaan masker di masa pandemi covid-19 pada masyarakat di kabupaten muna. Lit Inst. 2020;6(1):52-7.

7. Ulfah S, Candi C, Darmawan ES. Risk Factors of COVID-19 Transmission. Indonesia: $7^{\text {th }}$ International Conference on Public Health; 2020. p. 18-9.

8. Shah AS, Wood R. Risk of hospital admission with coronavirus disease 2019 in healthcare workers and their households: Nationwide linkage cohort study. BMJ. 2020;371:1-2. https://doi. org/10.1136/bmj.m3582.

9. Gan WH, Lim JW, Koh D. Preventing intra-hospital infection and transmission of coronavirus disease 2019 in healthcare workers. Saf Health Work. 2020;11(2):241-3. https://doi. org/10.1016/j.shaw.2020.03.001

10. Fenitra RM, Praptapa A, Suyono E, Kusuma P, Usman I. factors influencing preventive intention behavior towards covid-19 in Indonesia. J Behav Sci. 2021;16(1):14-27.

11. Ma C. An investigation of factors influencing self-care behaviors in young and middle-aged adults with hypertension based on a health belief model. Hear Lung. 2018;47(2):136-41. https://doi. org/10.1016/j.hrtlng.2017.12.001 PMid:29395265

12. Fikriana R, Devy SR, Nurhudi T, Qodriyah L. Factor analysis of patient with hypertension on self-regulation based on self-belief. J Global Pharma Technol. 2019;11(8):173-82.

13. Alhalaseh L, Fayoumi H, Khalil B. The Health Belief Model in predicting healthcare workers' intention for influenza vaccine uptake in Jordan. Vaccine. 2020;38(46):7372-8. https://doi. org/10.1016/j.vaccine.2020.09.002 PMid:32950300

14. Chu A, Harnicher BM, Castrellon BP, Bowers JA, Shan G. Using the health belief model to assess the impact of student pharmacist-led health outreach events. Curr Pharm Teach Learn. 2021;13(6):694-8. https://doi.org/10.1016/j.cptl.2021.01.031 PMid:33867066

15. Fauziah A. Analisis Faktor Yang Berhubungan Dengan Sel Acceptance Penderita HIV dan AIDS dalam Kelompok Dukungan Sebaya (KDS) Berdasarkan Teori Health Belief Model. Indonesia: Universitas Airlangga; 2017.

16. Nursalam N, Fikriana R, Devy SR, Ahsan A. The development of self-regulation models. Syst Reviwa Pharm. 2020;11(6):1036-41.

17. Fathian-Dastgerdi Z, Khoshgoftar M, Tavakoli B, Jaleh M. Factors associated with preventive behaviors of COVID-19 among adolescents: Applying the health belief model. Res Soc Adm Pharm. 2021;17(10):1786-90. https://doi.org/10.1016/j. sapharm.2021.01.014 PMid:33558153

18. Al-Noumani H, Wu JR, Barksdale D, Sherwood G, AlKhasawneh E, Knafl G, Health beliefs and medication adherence in patients with hypertension: A systematic review of quantitative studies. Patient Educ Couns. 2019;102(6):1045-56. https://doi.org/10.1016/j.pec.2019.02.022 PMid:30846205

19. Yang SO, Jeong GH, Kim SJ, Lee SH. Correlates of self-care behaviors among low-income elderly women with hypertension in South Korea. J Obstet Gynecol Neonatal Nurs. 2014;43(1):97106. https://doi.org/10.1111/1552-6909.12265 PMid:24354464

20. Khorsandi M, Fekrizadeh Z, Roozbahani N. Investigation of the effect of education based on the health belief model on the adoption of hypertension-controlling behaviors in the elderly. Clin Interv Aging. 2017;12:233-40. https://doi.org/10.2147/cia. s117142

\section{PMid:28184154}

21. Shojaei S, Farhadloo R, Aein A, Vahedian M. Effects of the health belief model (HBM)-based educational program on the nutritional knowledge and behaviors of CABG patients. J Tehran Heart Cent. 2016;11(4):181-6.

PMid:28496509

22. Fikriana R, Nursalam N, Devy SR, Ahsan A, Sasono TN, Qodriyah L. Factor analysis of patient with hypertension on self-regulation based on self-belief. J Glob Pharma Technol. 2019;11(8):173-82

23. Venema TA, Pfattheicher S. Perceived susceptibility to COVID-19 infection and narcissistic traits. Pers Individ Dif. 2021;175:110696. https://doi.org/10.1016/j.paid.2021.110696 PMid:33558779

24. Rachman BE, Rusli M, Miftahussurur M. The hidden vulnerability of COVID-19 observed from asymptomatic cases in Indonesia. Syst Rev Pharm. 2020;11(2):703-13.

25. Gilfoyle M, Garcia J, Chaurasia A, Oremus M. Perceived susceptibility to developing cancer and mammography screening behaviour: A cross-sectional analysis of Alberta's tomorrow project. Public Health. 2019;177:135-42. https://doi. org/10.1016/j.puhe.2019.08.004 PMid:31563701

26. Suryawan IG, Bakhriansyah J, Puspitasari M, Gandi P, Intan RE, Alkaff FF. To reperfuse or not to reperfuse: A case report of Wellens' syndrome with suspected COVID-19 infection. Egypt Heart J. 2020;72(1):58. https://doi.org/10.1186/ s43044-020-00094-w

PMid:32923003

27. Lee-Won RJ, Na K, Coduto KD. The effects of social media virality metrics, message framing, and perceived susceptibility on cancer screening intention: The mediating role of fear. Telemat Inform. 2017;34(8):1387-97. https://doi.org/10.1016/j. tele.2017.06.002

28. Gibson EG, Gage JC, Castle PE, Scarinci IC. Perceived susceptibility to cervical cancer among African American women in the mississippi delta: Does adherence to screening matter? Womens Health Issues. 2019;29(1):38-47. https://doi. org/10.1016/j.whi.2018.09.006

PMid:30401612

29. Soedarsono S. A family cluster of coronavirus disease (COVID-19) infection with different clinical manifestations. Acta Med Indones. 2020;52(2):155-62.

PMid:32778630

30. Shaheen AM, Hamdan KM, Alkaid Albqoor M, Arabiat DH Perceived barriers to healthcare utilization among Jordanian families: A family centered approach. Appl Nurs Res. 2020;54:151313. https://doi.org/10.1016/j.apnr.2020.151313 PMid:32650894

31. Amin MN, Uddin G, Uddin N, Rahaman Z, Siddiqui SA, Hossain S, et al. A hospital based survey to evaluate knowledge, awareness and perceived barriers regarding breast cancer screening among females in Bangladesh. Heliyon. 2020;6(4):e03753. https://doi.org/10.1016/j.heliyon.2020.e03753

32. Uldbjerg CS, Schramm S, Kaducu FO, Ovuga E, Sodemann M. Perceived barriers to utilization of antenatal care services in northern Uganda: A qualitative study. Sex Reprod Healthc. 2020;23:100464. https://doi.org/10.1016/j.srhc.2019.100464 PMid:31710878

33. Keaver L, McGough AM, Du M, Chang W, Chomitz V, Allen JD, et al. Self-reported changes and perceived barriers to healthy eating and physical activity among global breast 
cancer survivors: Results from an exploratory online novel survey. J Acad Nutr Diet. 2021;121(2):233-241.e8. https://doi. org/10.1016/j.jand.2020.09.031

PMid:33109503

34. Fragkaki I, Maciejewski DF, Weijman EL, Feltes J, Cima M Human responses to Covid-19: The role of optimism bias, perceived severity, and anxiety. Pers Individ Dif. 2021;176:110781. https://doi.org/10.1016/j.paid.2021.110781 PMid:33623178

35. Fikriana R, Afik A. Self-belief and social support factors on the emotional response of patients with hypertension. J Glob Pharma Technol. 2020;12(1):440-6.
36. Omar NA, Abdullah NL, Zainol Z, Nazri MA. Consumers responsiveness towards contaminated canned sardine in Malaysia: Does perceived severity matter? Food Control. 2021;123:107780. https://doi.org/10.1016/j. foodcont.2020.107780

37. Bray JK, Feldman SR. Demographics and the perceived severity of psoriasis symptoms, effect on daily life, and willingness to seek medical attention. JAAD Int. 2020;1(1):43-5. https://doi. org/10.1016/j.jdin.2020.04.002

38. Oruganti R, Paidipati S, Dinaker M. The health beliefs scale for hypertensive patients : Construction and psychometric testing. IOSR J Nurs Health Sci 2018;7(6):34-43. 